\title{
Characterisation of physicochemical properties of gum arabic powder at various particle sizes
}

\author{
${ }^{1}$ Rosland Abel, S.E, ${ }^{1,2, *}$ Yusof, Y.A., ${ }^{1}$ Chin, N.L., ${ }^{3}$ Chang, L.S., ${ }^{3}$ Mohd Ghazali, H. and \\ ${ }^{2}$ Manaf, Y.N. \\ ${ }^{1}$ Department of Process and Food Engineering, Faculty of Engineering, Universiti Putra Malaysia, 43400 \\ Serdang, Selangor, Malaysia \\ ${ }^{2}$ Laboratory of Halal Services, Halal Products Research Institute, Universiti Putra Malaysia, \\ 43400 Serdang, Selangor, Malaysia \\ ${ }^{3}$ Department of Food Science, Faculty of Food Science and Technology, Universiti Putra Malaysia, 43400 \\ Serdang, Selangor, Malaysia
}

\begin{abstract}
Article history:
Received: 5 September 2019

Received in revised form: 17

October 2019

Accepted: 16 November 2019

Available Online: 10

February 2020
\end{abstract}

\section{Keywords:}

Gum arabic,

Gelatin,

Powder,

Particle size,

Density,

Morphology

DOI:

https://doi.org/10.26656/fr.2017.4(S1).S32

\begin{abstract}
Plant gum exudate, such as gum arabic, is extensively used in a variety of industrial applications due to their emulsification, microencapsulation and stabilisation properties. The present study is aimed to investigate the effect of particle size on the proximate composition, the density and the physicochemical properties of the gum arabic powder. The classification of particle size based on the mean diameter $\left(d_{50}\right)$ ranged between 30 to $800 \mu \mathrm{m}$. Based on the proximate composition results, the coarse $(414 \mu \mathrm{m})$ and very coarse $(790 \mu \mathrm{m})$ particles yielded a similar moisture content of $13.8 \%$, which was higher than that of the commercial gum (11.1\%). Meanwhile, the medium coarse $(208 \mu \mathrm{m})$ particles contain higher fiber content $(97.9 \%)$ as compared to other particle sizes. The bulk and tapped density of the gum were significantly affected by the particle size. Water activity analysis indicated that the gum arabic is microbiologically safe, as it has poor condition or environment for microbial growth. From the hygroscopicity analysis, it was found that the very fine $(37 \mu \mathrm{m})$ particles obtained the highest hygroscopicity value of $40 \%$. The swelling index of medium coarse $(208 \mu \mathrm{m})$ particles was closed to that of the commercial gum. The emulsion capacity $(E C)$ and emulsion stability $(E S)$ analyses observed that the very coarse $(790 \mu \mathrm{m})$ and very fine $(37 \mu \mathrm{m})$ particles recorded the highest $E C$ and $E S$ values of $93 \%$ and $89 \%$, respectively. The glass transition temperature was not significantly affected by the particle size. The colour analysis indicated that the commercial gum is lighter (71.4) than the other particle sizes. Meanwhile, the very fine $(37 \mu \mathrm{m})$ and fine $(85 \mu \mathrm{m})$ particles exhibited similar redness $\left(a^{*}\right)$ value with that of the commercial gum, with a value recorded at 3.7. The morphology analysis observed that the gum exhibited irregular shape with rough granule surfaces. The present work revealed that coarse $(208$ to $414 \mu \mathrm{m})$ particles showed better characteristics compared to that of the commercial gum arabic that is available in the market.
\end{abstract}

\section{Introduction}

Gum exudates are used as an ingredient in many applications, including food, pharmaceutical, cosmetic, and paper industries (Whistler, 1993; Nussinovitch, 1997; Tan, 2004; Bhushette and Annapure, 2018; Zhang et al., 2019). In the food industry, gum arabic is being widely used either as an emulsifier, a foaming agent or an encapsulating material. Gum arabic is believed to have a higher ability to hydrate, swell, dissolve, and interact with water; resulting in an improved effectiveness in emulsion stability (Elizalde et al., 1988;
Al-Assaf et al., 2007; Li et al., 2018; Moradi and Anarjan, 2019). It is extensively used as emulsifiers in the manufacture of soft drinks and oil-in-water emulsions, such as the orange-oil beverage (Tan, 2004; Pua et al., 2007). As a foaming agent, gum arabic is mostly used in confectionary and beverages due to its lower viscosity and higher solubility characteristics (Makri and Doxastakis, 2006; Walsh et al., 2008; Jiang et al., 2013). In spray drying process, the most common carrier agents used for microencapsulation are the maltodextrin and gum arabic (Righetto and Netto, 2005; Gabas et al., 2007; Mosquera et al., 2011; Liang et al., 
2012; Niu et al., 2018). Gum arabic is often selected as the encapsulating material due to its good emulsifying capacity, which increases the microencapsulation efficiency.

Gelatin is a substantially pure protein food ingredient obtained through the thermal denaturation of collagen, in which it is a structural mainstay and the most common protein in the animal kingdom (Bailey and Paul, 1998). Recently, there is a trend on the increasing number of new applications of gelatin in the food industry. The food industry uses gelatin for various purposes, such as an ingredient in jellies, desserts, yogurts, ice creams, and marshmallows (Venien and Levieux, 2005). On the other hand, gelatin is also used as a biodegradable matrix material in implantable delivery systems, a binder in tablets, as well as a matrix in the microencapsulation of drugs in the pharmaceutical industry. According to Ahmad and Benjakul (2011), it was learnt that the highest production of gelatin was from pigskin (44\%), followed by bovine hides (28\%), bovine bones $(27 \%)$, and other sources $(1 \%)$. However, the use of products containing gelatin from pigskin are prohibited for followers of religions such as Islam and Judaism. Therefore, gum arabic was proposed to replace gelatin in various product applications. Gum arabic has its own unique properties and functionalities that can benefit the end consumer in a food development process. To select industry-appropriate particle sizes, a clear understanding on the physical and functional properties is important. There are limited reports available on particle size dependency in the physicochemical properties of food materials. Hence, a comprehensive understanding of the above-mentioned properties could help in handling applications and quality control, avoid potential flow issues, and aid the ingredient selection for manufacturing purposes. Overall, this study is aimed to investigate the effects of different particle sizes on the physical properties of gum arabic powder, and to compare it with that of the commercial gum arabic that is available in the market.

\section{Materials and methods}

\subsection{Sample preparation}

The dried exudate gum arabic and commercial gum was purchased from a local dry market located in Selangor, Malaysia. The gum arabic was washed under running tap water to remove the surface dirt. Then, it was dried in an oven (Memmert Oven, Germany) at $60 \pm 2^{\circ} \mathrm{C}$ for $24 \mathrm{hrs}$. Mortar and pestle were used to grind the dried material, which was followed by a sieving process for 20 mins using a vertical vibratory sieve shaker (Labortechnik GmbH, Ilmenau). Five different sieves with an aperture size of $63,125,250,500$ and $1000 \mu \mathrm{m}$ were used to collect the varying particle sizes required for this study. Finally, the powder was packed in polyethylene zipped bags $(12 \mathrm{~cm} \times 12 \mathrm{~cm})$ and stored at $4 \pm 2^{\circ} \mathrm{C}$ prior to analysis.

\subsection{Particle size analyzing}

The particle size distribution of gum arabic powder was determined using a dry dispersion unit of Malvern Mastersizer 2000 particle size analyzer (Malvern Instrument Ltd, Worcestershire, UK). About $1 \mathrm{~g}$ of powder was placed in a stirring cell (volume $10 \mathrm{~mL}$ ) with an obscurity value of 0.12 to 0.18 with the air pressure set to 2.0 bars. The classification of particle sizes is shown in Table 1.

Table 1. Classification of particle sizes

\begin{tabular}{lccc}
\hline $\begin{array}{c}\text { Classification } \\
\text { of powder }\end{array}$ & $\begin{array}{c}\text { Sieve opening } \\
(\mu \mathrm{m})^{\mathrm{a}}\end{array}$ & Mesh size $(\mu \mathrm{m})^{\mathrm{b}}$ & $d_{50}(\mu \mathrm{m})$ \\
\hline Very coarse & $>1000$ & 230 & $790 \pm 0.14$ \\
Coarse & $355-1000$ & 120 & $414 \pm 0.07$ \\
Moderately & $180-355$ & 60 & $208 \pm 0.37$ \\
fine & $125-180$ & 35 & $85 \pm 0.05$ \\
Fine & $<125$ & 18 & $37 \pm 0.02$ \\
\hline
\end{tabular}

${ }^{a}$ The United States Pharmacopeia Convention, Inc. Chapter

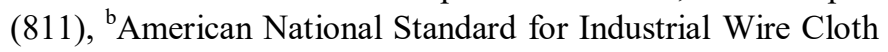
(American Standard ASTM-E11)

\subsection{Proximate analysis}

The proximate analyses of moisture, ash, crude protein, crude lipid, and dietary fiber of the gum arabic powder were analysed according to the AOAC methods (AOAC, 2002). The moisture content of the sample was measured using the oven drying method at $105^{\circ} \mathrm{C}$ for 24 hrs. In order to determine the ash content, the samples were incinerated at $550^{\circ} \mathrm{C}$ for $6 \mathrm{hrs}$. Whereas, Kjeldahl method ( $\mathrm{N} \times$ 6.25), Soxtech (Model-2050 Foss, Denmark) and Fibertech (Model-2010 Foss, Denmark) were used to measure the total protein, fat and fiber contents, respectively. Total carbohydrate content was determined by the difference $[100-$ (moisture + ash + protein + lipid)].

\subsection{Density analysis}

\subsubsection{True density}

A gas pycnometer (AccuPyc II 1340, Micromeritics, Norcross, USA) was used to measure the true density. This device used the gas displacement method for an accurate volume measurement. Once the sample was placed in a chamber with a known volume, the helium gas was released and allowed to expand into the other precision internal volume. The sealed chamber with the sample in it was then pressurised to achieve the desired pressure with gas displacement. The pressure was recorded upon stabilisation. Once stabilised, the gas was 
allowed to expand into a reference chamber with a known volume when the valve is opened. Once the pressure in the reference chamber stabilised, the second pressure was recorded. The solid phase volume was calculated based on the pressure record of the sample chamber and the reference chamber. Next, the gas displacement density was measured by dividing the solid phase volume into the sample weight. The sample weight was estimated when the helium molecules had filled pores that are as small as one angstrom in diameter, whereby the gas was displaced only by the solid phase of the sample.

\subsubsection{Bulk density}

Approximately $2 \mathrm{~g}$ of gum arabic powder, $m$, was transferred to a $10 \mathrm{~mL}$ graduated cylinder and the volume of the sample powder occupied $\left(V_{b}\right)$ was recorded. The bulk density $\left(\rho_{b}\right)$ was determined using the following equation:

$$
\rho_{b}=\frac{m}{V_{h}}
$$

\subsubsection{Tapped density}

Approximately $2 \mathrm{~g}$ of gum arabic powder, $m$, was transferred to a $10 \mathrm{~mL}$ graduated cylinder and the cylinder was mechanically tapped up and down 100 times. Then, the volume that the sample powder occupied $\left(V_{t}\right)$ was recorded. The tapped density $\left(\rho_{t}\right)$ was calculated using the following equation:

$$
\rho_{t}=\frac{m}{V_{t}}
$$

\subsubsection{Hausner ratio}

Hausner ratio $(H R)$ is an index that corresponds to the flowability of a powder or granular material (Hausner, 1967). It was determined using the following equation:

$$
H R=\frac{\rho_{t}}{\rho_{h}}
$$

Where, $\rho_{t}$ is tapped density, $\rho_{b}$ is bulk density.

\subsubsection{Carr index}

Carr index $(C I)$ or Carr's compressibility index is an indication of the compressibility of a powder (Carr, 1965). It was determined using the following equation:

$$
C I=\frac{\rho_{t}-\rho_{b}}{\rho_{t}} \times 100
$$

Where, $\rho_{t}$ is tapped density, $\rho_{b}$ is bulk density.

\subsubsection{Angle of repose}

The angle of repose was determined manually by calculating the dimensions of the powder pile. The powder was passed through a lifted funnel to form a powder heap. Then, the angle of repose $(\theta)$ was calculated by measuring the radius $(r)$ of the base and height $(h)$ of the conical powder heap formed using the formula below:

$$
\tan \theta=\frac{h}{r}
$$

\subsection{Water activity}

Water activity of gum arabic was measured using a water activity meter (Model 3TE, Aqualab, WA). Approximately $2 \mathrm{~g}$ of the powdered sample was filled into a sample cup and the water activity was determined at room temperature $\left(25 \pm 1^{\circ} \mathrm{C}\right)$.

\subsection{Hygroscopicity}

Approximately $1 \mathrm{~g}$ of gum arabic powder was placed in a sealed humidity desiccator containing a saturated sodium chloride solution ( $76 \pm 2 \%$ relative humidity) and was incubated at $25 \pm 1^{\circ} \mathrm{C}$ for one week. The hygroscopicity $(H G)$ value was determined using the following equation:

$$
H G=\frac{W_{2}-W_{1}}{W_{1}} \times 100
$$

Where, $W_{2}$ is the weight of powder after equilibrium and $W_{l}$ is the initial mass of powder.

\subsection{Swelling index}

Approximately $5 \mathrm{~g}$ of gum arabic powder was transferred gently into a $200 \mathrm{~mL}$ measuring cylinder where the bulk volume, $\mathrm{V}_{1}$ was measured. Then, distilled water was added to disperse the gum until the volume reaches the $100 \mathrm{~mL}$ mark. The dispersion was allowed to stand for $24 \mathrm{hrs}$ and the volume of the swollen gum, $\mathrm{V}_{2}$ was recorded. All measurements were performed in duplicates. The swelling index $(S I)$ was determined using the following equation:

$$
S I=\frac{V_{2}}{V_{1}}
$$

\subsection{Emulsion capacity}

The emulsification capacity $(E C)$ yielded from the gum arabic used in this study was compared with the commercial gum. Gum arabic aqueous solutions were prepared with water to produce 5 dispersions. Commercial corn oil $(1 \% \mathrm{v} / \mathrm{v})$ was added to these dispersions. The amount of gum arabic in each dispersion was adjusted to yield $0.1,0.25,0.50,0.75$, $1.0 \% \mathrm{w} / \mathrm{v}$ concentration in the final mixture. A vortex was used to homogenize each mixture for $1 \mathrm{~min}$. Finally, all 5 dispersions were centrifuged at $800 \times \mathrm{g}$ for 10 mins. The $E C$ was calculated using the following equation (Sciarini et al., 2009): 


$$
E C=\frac{e_{v}}{t_{v}} \times 100
$$

where, $e_{v}$ is the emulsion volume and $t_{v}$ is total volume.

\subsection{Emulsion stability}

The emulsion stability $(E S)$ against high temperature was estimated by incubating the solution at $80^{\circ} \mathrm{C}$ for 30 mins in a water bath. The solution was centrifuged at 800 $\mathrm{x} g$ for 10 mins following incubation. The calculation involved to determine ES is shown below (Sciarini et al., 2009).

$$
E S=\frac{f_{e v}}{i_{e v}} \times 100
$$

where, $f_{e v}$ is final emulsion volume, and $i_{e v}$ is initial emulsion volume.

\subsection{Glass transition temperature}

A differential scanning calorimetry (DSC7 Perkin Elmer, Norwalk, Conn., U.S.A.) equipped with a temperature control system using liquid nitrogen (Perkin Elmer Intra Cooler 2 control cooling accessory) were used for the measurement of the glass transition temperature. An empty reference pan was prepared. Then, saturated salt solutions in a desiccator at $25^{\circ} \mathrm{C}$ was used to equilibrate the $5 \mathrm{mg}$ of gum arabic powder which was placed in DSC aluminum pans until the equilibrium was achieved. Upon reaching equilibrium, the samples were sealed using hermetic lids for further analysis and weighing. The cooling system using liquid nitrogen was employed for test temperatures below $70^{\circ} \mathrm{C}$. Meanwhile, for test temperatures above $70^{\circ} \mathrm{C}$, a mechanical refrigerated cooling accessory system (RCS) was used. Dry helium at $250 \mathrm{~mL} / \mathrm{min}$, was used as the purge gas. Once the sample was cooled to $-60^{\circ} \mathrm{C}$, the scanning was performed by heating the sample at a rate of $10^{\circ} \mathrm{C} / \mathrm{min}$ from $-60^{\circ} \mathrm{C}$ to $100^{\circ} \mathrm{C}$. The results of the glass transition temperature exhibited an endothermic shift in the specific heat capacity, which yielded a discontinuity in the baseline. Each sample was also subjected to a second scanning to reduce the enthalpy relation of the amorphous powder, which appears in the first scan. Every measurement was done in duplicates where all the readings were recorded.

\subsection{Colour analysis}

The Hunter Colour Lab (Colorflex) was used to measure the colour analysis. The results were expressed as $L^{*}, a^{*}$ and $b^{*}$, where $L^{*}$ (lightness), $a^{*}$ as redness $(+)$ and greenness (-), and $b^{*}$ as yellowness $(+)$ and blueness $(-)$. The standard black and white tile was used for the calibration of the instrument $\left(L^{*}=90.55, a^{*}=-0.71, b^{*}=\right.$ $0.39)$, prior to sample measurements.

\subsection{Morphological analysis}

The surface texture and morphology of gum arabic powder were studied using the Field Emission Scanning Electron Microscope (FESEM), Carl Zeiss Supra 55VP, and JEOL JSM-7600F. The morphological characterisation was performed by mounting a small amount of powder on the FESEM stubs, and the accelerating voltage and magnification were set at 5.0 $\mathrm{kV}$ and 100x for observation.

\subsection{Statistical analysis}

The measurements were done in duplicates and expressed as arithmetic mean data ( \pm standard deviations). The Minitab Statistical Software (Version 16, Minitab Corp, USA) was used to perform the regression analysis of variance (ANOVA). The Tukey's test was employed to determine sample groups with a significant difference at $95 \%$ confidence level $(P<0.05)$.

\section{Results and discussion}

\subsection{Proximate composition}

Table 2 represents the proximate composition of gum arabic at various particle sizes. The proximate compositions measured are the moisture, ash, protein, lipid, fiber and carbohydrate contents. The moisture content had ranged from 11.1 to $11.7 \%$ and the values observed were within the international specifications of 11 to $15 \%$. It can be seen that, the very coarse $(790 \mu \mathrm{m})$ particles yielded a higher moisture content of $13.8 \%$ compared with that of the commercial gum (11.1\%). Meanwhile, the ash content that varied from 3.6 to 3.9\% was also within the acceptable range of less than $4 \%$ for food and pharmaceutical quality of gum arabic (FAO, 1998). This finding was in agreement with Jani et al. (2016), which recorded the values of $13.40 \%$ and $3.42 \%$ for moisture and ash contents, respectively. On the other hand, Dziki (2011) also indicated that the moisture content of wheat kernels was found to have increased with increasing particle size. The moisture content of wheat kernels had ranged between 10 and $20 \%$ for particle size within the range of 0.25 to $2.00 \mathrm{~mm}$. For dietary fiber analysis, the values obtained had ranged from 89.1 to $97.9 \%$, where the very coarse $(790 \mu \mathrm{m})$ particles contained the lowest dietary fiber when compared to other particle sizes. Meanwhile, the protein, lipid and carbohydrate contents had ranged from 22.0 to $2.4 \%, 0.1$ to $0.6 \%$ and 79.9 to $82.1 \%$, respectively. It was observed that the protein, lipid and carbohydrate contents were not significantly affected by the particle size. The proximate analysis shows that the very fine $(37 \mu \mathrm{m})$ particles indicated no significant difference $(P>0.05)$ with the commercial gum arabic, whereas, the coarse $(414 \mu \mathrm{m})$ and very coarse $(790 \mu \mathrm{m})$ particles showed 
Table 2. Proximate composition of gum arabic powder

\begin{tabular}{ccccccc}
\hline \multirow{2}{*}{$\mathrm{d}_{50}(\mu \mathrm{m})$} & \multicolumn{7}{c}{ Proximate composition $(\%)$} \\
\cline { 2 - 7 } & Moisture & Ash & Protein & Lipid & Dietary fiber & Carbohydrate \\
\hline 37 & $11.7 \pm 0.1^{\mathrm{c}}$ & $3.6 \pm 0.0^{\mathrm{b}}$ & $2.3 \pm 0.0^{\mathrm{a}}$ & $0.3 \pm 0.0^{\mathrm{a}, \mathrm{b}, \mathrm{c}}$ & $95.5 \pm 1.2^{\mathrm{a}, \mathrm{b}}$ & $82.1 \pm 0.1^{\mathrm{a}}$ \\
85 & $13.5 \pm 0.1^{\mathrm{b}}$ & $3.6 \pm 0.0^{\mathrm{b}}$ & $2.0 \pm 0.0^{\mathrm{b}}$ & $0.2 \pm 0.1^{\mathrm{b}, \mathrm{c}}$ & $93.2 \pm 0.2^{\mathrm{b}}$ & $80.7 \pm 0.2^{\mathrm{b}, \mathrm{c}}$ \\
208 & $13.7 \pm 0.1^{\mathrm{a}, \mathrm{b}}$ & $3.6 \pm 0.0^{\mathrm{b}}$ & $2.2 \pm 0.0^{\mathrm{b}}$ & $0.1 \pm 0.0^{\mathrm{c}}$ & $97.9 \pm 0.3^{\mathrm{a}}$ & $80.4 \pm 0.1^{\mathrm{b}, \mathrm{c}}$ \\
414 & $13.7 \pm 0.0^{\mathrm{a}, \mathrm{b}}$ & $3.7 \pm 0.0^{\mathrm{a}, \mathrm{b}}$ & $2.0 \pm 0.0^{\mathrm{b}}$ & $0.6 \pm 0.0^{\mathrm{a}}$ & $97.8 \pm 0.5^{\mathrm{a}}$ & $79.9 \pm 0.0^{\mathrm{b}}$ \\
790 & $13.8 \pm 0.1^{\mathrm{a}}$ & $3.9 \pm 0.0^{\mathrm{a}}$ & $2.0 \pm 0.0^{\mathrm{b}}$ & $0.2 \pm 0.0^{\mathrm{b}, \mathrm{c}}$ & $89.1 \pm 0.5^{\mathrm{c}}$ & $80.1 \pm 0.1^{\mathrm{b}, \mathrm{c}}$ \\
Commercial & $11.1 \pm 0.1^{\mathrm{d}}$ & $3.9 \pm 0.0^{\mathrm{a}}$ & $2.4 \pm 0.0^{\mathrm{a}}$ & $0.5 \pm 0.1^{\mathrm{a}, \mathrm{b}}$ & $96.5 \pm 0.1^{\mathrm{a}, \mathrm{b}}$ & $82.0 \pm 0.2^{\mathrm{a}}$ \\
\hline
\end{tabular}

Different letters in the same column indicate significant differences $(P<0.05)$ between the samples

Table 3. Density properties of gum arabic powder

Powder properties

$\begin{array}{cccccccc}d_{50}(\mu \mathrm{m}) & \begin{array}{c}\text { True density, } \\ \mathrm{g} / \mathrm{cm}^{3}\end{array} & \begin{array}{c}\text { Bulk density, } \\ \mathrm{g} / \mathrm{cm}^{3}\end{array} & \begin{array}{c}\text { Tapped density, } \\ \mathrm{g} / \mathrm{cm}^{3}\end{array} & \begin{array}{c}\text { Hausner } \\ \text { ratio }\end{array} & \begin{array}{c}\text { Carr index, } \\ \%\end{array} & \begin{array}{c}\text { Angle of } \\ \text { repose, }\end{array} & \text { Flow behaviour } \\ \text { (Carr, 1965; Hausner, 1967) }\end{array}$

Different letters in the same column indicate significant differences $(P<0.05)$ between the samples

significant differences when compared with the commercial gum.

\subsection{Density properties}

Table 3 represents the density properties of gum arabic at various particle sizes. The density properties measured are true, bulk and tapped densities. The values obtained were in the range of 1.48 to $1.49 \mathrm{~g} / \mathrm{cm}^{3}, 0.59$ to $0.74 \mathrm{~g} / \mathrm{cm}^{3}$ and 0.73 to $0.84 \mathrm{~g} / \mathrm{cm}^{3}$ for true, bulk and tapped densities, respectively. The findings of this study found that the particle size has a significant effect on the bulk and tapped densities; however, no effect can be seen on the true density of the samples. As predicted, both bulk and tapped densities had significantly increased with an increase in the particle size. The very coarse $(790 \mu \mathrm{m})$ particles had the highest values of bulk and tapped densities, which were recorded at 0.79 and $0.89 \mathrm{~g} /$ $\mathrm{cm}^{3}$, respectively. The bulk and tapped densities obtained for the studied samples were slightly higher compared with that of the commercial gum, with values recorded at 0.63 and $0.83 \mathrm{~g} / \mathrm{cm}^{3}$, respectively. The values obtained in this study were higher than the values found by Gayathri and Ganapathy (2018), with values reported at 0.53 and $0.57 \mathrm{~g} / \mathrm{cm}^{3}$ for bulk and tapped densities, respectively.

Particle size can be correlated with powder compressibility. However, it is not a direct measure of flowability; instead, it provides a useful indication of the flow properties. Carr (1965) reported that the compressibility of powder refers to its capability of affecting the flow properties through micro-scale adhesion forces between the particles. The findings of this study showed that the compressibility index and angle of repose of the gum powder ranged from 11.25 to $19.11 \%$ and 20.44 to $26.28^{\circ}$, respectively. Based on the standard compressibility index values, 11 to $15 \%$ indicate good flow characteristics (USP30 NF 25). Meanwhile, angle of repose values of less than $25^{\circ}$ indicates excellent flow; whereby a reading between 25 and $30^{\circ}$ indicates good flow characteristics without the addition of flow promoters. The measurements indicated that the very coarse $(790 \mu \mathrm{m})$ particles had lower compressibility index and angle of repose, with values reported at $11.89 \%$ and $20.44^{\circ}$, respectively. This could be due to the decrease in cohesive force between the larger granules, resulting in an increase in the binding level of the granules (Onunkwo, 2010). For smaller particles, the flowability characteristic worsens due to the particle shrinking in size, resulting in an increase in particle surface area per unit mass. Therefore, an enlarged surface area would result in surface cohesive force, leading to greater cohesive effects (Fitzpatrick et al., 2004). The results obtained were in the agreement with previous work by Ogunjimi and Alebiowu (2013), where the values obtained were 1.21 and $22.69^{\circ}$ for Hausner ratio and angle of repose, respectively. Besides that, similar flowability behaviour was observed for tea and salt powders (Teunou and Fitzpatrick, 2000; Fitzpatrick et al., 2004). They indicated that tea and milk powders with particle size of less than $25 \mu \mathrm{m}$ exhibited poor flowability; whereas, the particle size of more than $200 \mu \mathrm{m}$ exhibited better flowability. 


\subsection{Physicochemical properties}

Table 4 represents the physicochemical properties of gum arabic at various particle sizes. In the current study, the water activity of gum arabic ranged between 0.52 and 0.56 , which was slightly higher compared to that of the commercial gum (0.45). These values indicate that the gum arabic is microbiologically safe, as low water activity limits microbial growth. Overall, the water activity was not significantly affected by the particle size. Meanwhile, the hygroscopicity of the gum ranged from 26 to $40 \%$, whereby the very fine $(37 \mu \mathrm{m})$ particles with the highest value of $40 \%$ presented a great capacity to retain and adsorb water. This study shows that the hygroscopicity increased with decreasing particle size, indicating gum with smaller size has a higher tendency to absorb moisture from the surrounding environment. This phenomenon can be explained due to the smaller particle size exhibits higher surface area, which will in turn promote moisture absorption. On the other hand, the swelling index $(S I)$ of the gum ranged from 1.56 to 4.00 . It was observed that the $S I$ value had increased with increasing particle size, indicating higher retention of water-swollen granules for larger particle size. It was found that the very coarse $(790 \mu \mathrm{m})$ particles had obtained the highest SI (4.00), which is slightly higher compared to that of the commercial gum arabic (2.00).

The emulsion capacity $(E C)$ and emulsion stability $(E S)$ of gum dispersions had ranged from 83.33 to $93.33 \%$ and 60.71 to $88.80 \%$, respectively. The very coarse $(790 \mu \mathrm{m})$ particles tested in this study recorded the highest $E C$ value of $93 \%$, revealing that its large particle size had a higher ability to form emulsion with oil. Apart from that, the above-mentioned $E C$ value was found to be higher than that of the commercial gum $(87 \%)$. On the other hand, the finest $(37 \mu \mathrm{m})$ particles demonstrated the highest $E S$ value (89\%) compared to the commercial gum $(75 \%)$. The difference in $E S$ could be due to the presence of high percentage of residual lipids and lower protein content in the commercial gum powder, which led to the poor emulsifying properties. These properties are commonly affected by the surfaceactive molecules, such as proteins, due to their amphiphilic nature and capability of lowering the surface tension. Moreover, the low hydrophobicity of the gum would prevent the interaction between the proteins and the oils, thus restricting the emulsifying properties (Hailing, 1981; Philips et al., 1994).

According to the differential scanning calorimeter readings, the glass transition temperature $\left(T_{G}\right)$ of the gum arabic had ranged from 56.18 to $57.62^{\circ} \mathrm{C}$, demonstrating that the gum was relatively stable at room temperature and had maintained in the glassy phase. It was observed that the fine $(85 \mu \mathrm{m})$ particles had obtained the highest $T_{G}$, which was recorded at $57.62^{\circ} \mathrm{C}$. Materials with higher $T_{G}$ values signify greater crystallinity (Donovan, 1979; Hover, 2001). A higher degree of crystallinity is proven to yield greater structural stability, where granules become more heat resistant (Singh et al., 2003; Ezekiel et al., 2007; Mathew and Abraham, 2007). This implies that the gum arabic is structurally stable and highly resistant to heat. It was also learnt that the particle size did not exhibit any significant effect on the glass transition temperature of the gum.

\subsection{Colour analysis}

Table 5 represents the colour analysis of gum arabic at various particle sizes. The results were expressed in terms of $L^{*}$ (lightness), $a^{*}$ (redness and greenness), and $b^{*}$ (yellowness and blueness). The $L^{*}, \mathrm{a}^{*}$, and $b^{*}$ values had ranged between 60.3 and 69.1, 3.7 and 4.2, and 20.9 to 24.6 , respectively. The colour values varied greatly with different particle sizes. It was observed that the $L^{*}$ value was found to have decreased with increasing particle size; this resulted in a darker powder. Meanwhile, the $a^{*}$ value was found to have increased with an increase in particle size; therefore, powder with bigger particle size has a more intense yellow colour. According to Table 5 , the fine $(85 \mu \mathrm{m})$ particles had the lowest $b^{*}$ values, which can be explained due to the increased specific surface area of the particles, hence, resulting in the material to emit intense colour values. The commercial gum had a lighter colour $\left(L^{*}=71.4\right)$ compared with those of other particle sizes. In the meantime, the $a^{*}$ value for very fine $(37 \mu \mathrm{m})$ and fine

Table 4. Physicochemical properties of gum arabic powder

\begin{tabular}{lcccccc}
\hline & \multicolumn{5}{c}{$d_{50}(\mu \mathrm{m})$} \\
\cline { 2 - 7 } Powder properties & 37 & 85 & 208 & 414 & 790 & Commercial \\
\hline Water activity & $0.52 \pm 0.00^{\mathrm{b}}$ & $0.56 \pm 0.00^{\mathrm{a}}$ & $0.56 \pm 0.00^{\mathrm{a}}$ & $0.56 \pm 0.00^{\mathrm{a}}$ & $0.56 \pm 0.00^{\mathrm{a}}$ & $0.45 \pm 0.00^{\mathrm{c}}$ \\
Hygroscopicity, \% & $39.75 \pm 0.02^{\mathrm{a}}$ & $28.15 \pm 0.39^{\mathrm{b}}$ & $28.01 \pm 0.22^{\mathrm{b}}$ & $26.14 \pm 2.90^{\mathrm{b}}$ & $26.00 \pm 1.21^{\mathrm{b}}$ & $30.36 \pm 0.95^{\mathrm{b}}$ \\
Swelling index & $1.56 \pm 0.06^{\mathrm{d}}$ & $1.63 \pm 0.13^{\mathrm{d}}$ & $1.71 \pm 0.04^{\mathrm{c}, \mathrm{d}}$ & $2.50 \pm 0.00^{\mathrm{b}}$ & $4.00 \pm 0.00^{\mathrm{a}}$ & $2.00 \pm 0.00^{\mathrm{c}}$ \\
Emulsion capacity, \% & $83.33 \pm 0.00^{\mathrm{f}}$ & $86.67 \pm 0.00^{\mathrm{c}}$ & $86.67 \pm 0.00^{\mathrm{b}}$ & $83.33 \pm 0.00^{\mathrm{e}}$ & $93.33 \pm 0.00^{\mathrm{a}}$ & $86.67 \pm 0.00^{\mathrm{d}}$ \\
Emulsion stability, \% & $88.80 \pm 0.80^{\mathrm{a}}$ & $69.62 \pm 0.38^{\mathrm{c}}$ & $78.85 \pm 1.93^{\mathrm{b}}$ & $82.00 \pm 2.00^{\mathrm{a}, \mathrm{b}}$ & $60.71 \pm 0.00^{\mathrm{d}}$ & $75.00 \pm 1.92^{\mathrm{b}, \mathrm{c}}$ \\
Glass Transition temperature, ${ }^{\circ} \mathrm{C}$ & $56.18 \pm 1.78^{\mathrm{a}}$ & $57.62 \pm 3.32^{\mathrm{a}}$ & $56.82 \pm 3.83^{\mathrm{a}}$ & $57.16 \pm 0.88^{\mathrm{a}}$ & $56.43 \pm 4.33^{\mathrm{a}}$ & $57.40 \pm 0.48^{\mathrm{a}}$ \\
\hline
\end{tabular}

Different letters in the same row indicate significant differences $(P<0.05)$ between the samples 


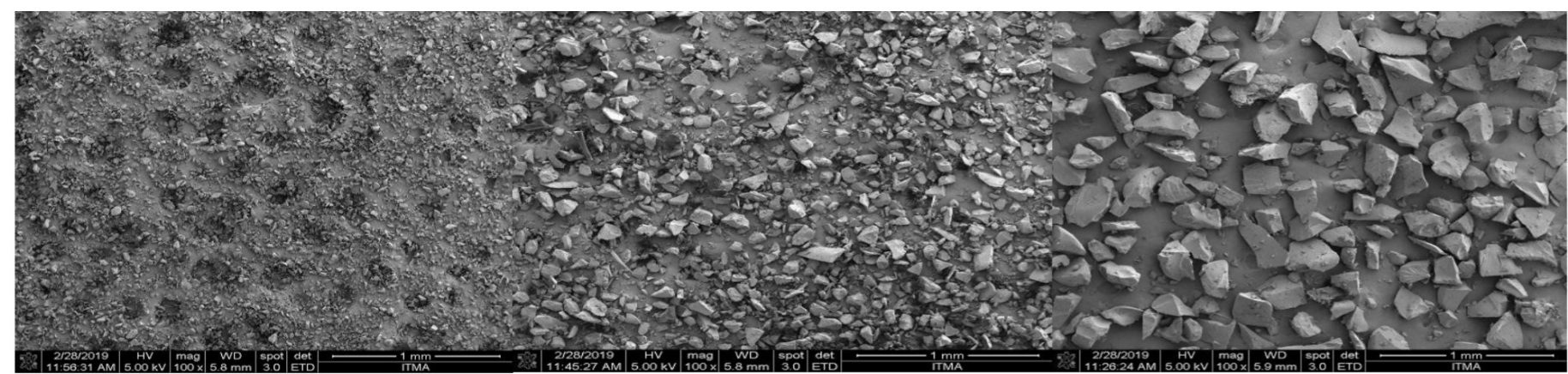

(a) $37 \mu \mathrm{m}$

(b) $85 \mu \mathrm{m}$

(c) $208 \mu \mathrm{m}$

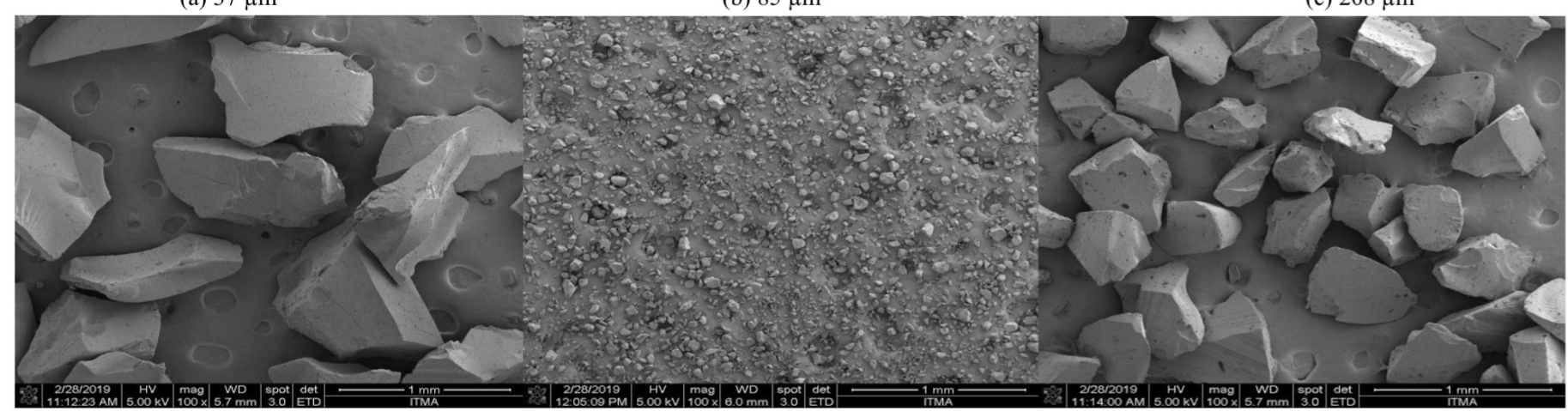

(d) $414 \mu \mathrm{m}$

(e) $790 \mu \mathrm{m}$

(f) Commercial

Figure 1. Morphology characteristics of gum arabic powder

$(85 \mu \mathrm{m})$ particles was similar to that of the commercial gum $\left(a^{*}=3.7\right)$. On the other hand, the coarse $(414 \mu \mathrm{m})$ particles exhibited greater intensity of yellowness $\left(b^{*}=24.6\right)$ than that of the commercial gum $\left(b^{*}=21.4\right)$.

Table 5. Colour analysis of gum arabic powder

\begin{tabular}{cccc}
\hline$d_{50}(\mu \mathrm{m})$ & $L^{*}$ value & $a^{*}$ value & $b^{*}$ value \\
\hline 37 & $69.1 \pm 0.10^{\mathrm{b}}$ & $3.7 \pm 0.05^{\mathrm{b}}$ & $21.3 \pm 0.05^{\mathrm{c}}$ \\
85 & $68.9 \pm 0.15^{\mathrm{b}}$ & $3.7 \pm 0.00^{\mathrm{b}}$ & $20.9 \pm 0.00^{\mathrm{c}}$ \\
208 & $65.8 \pm 0.00^{\mathrm{c}}$ & $3.9 \pm 0.00^{\mathrm{a}, \mathrm{b}}$ & $23.4 \pm 0.10^{\mathrm{b}}$ \\
414 & $62.5 \pm 0.05^{\mathrm{d}}$ & $4.2 \pm 0.05^{\mathrm{a}}$ & $24.6 \pm 0.00^{\mathrm{a}}$ \\
790 & $60.3 \pm 0.15^{\mathrm{e}}$ & $4.2 \pm 0.10^{\mathrm{a}}$ & $23.9 \pm 0.20^{\mathrm{b}}$ \\
Commercial & $71.4 \pm 0.10^{\mathrm{a}}$ & $3.7 \pm 0.05^{\mathrm{b}}$ & $21.4 \pm 0.05^{\mathrm{c}}$ \\
\hline
\end{tabular}

Different letters in the same column indicate significant differences $(P<0.05)$ between the samples

\subsection{Morphological characteristics}

Figure 1 illustrates the morphology of gum arabic at various particle sizes. The powder was assessed via Field Emission Scanning Electron Microscope (FESEM). It was observed that the gum exhibited irregular shape with rough granule surfaces. The particles have a rough surface morphology that can help in attaining highlyviscous aqueous solution. This observation is consistent with Ohwoavworhua and Adelakun (2005), who stated that the intrinsic viscosity and molecular mass of exudate gums are significantly influenced by the particle size and specific surface area. Meanwhile, the particle shape of the powder can be irregular, although the average sizes are grouped uniformly through sieving technique. Such irregular shapes of the powder might also influence its flow properties. Therefore, understanding these properties could aid in the selection of application based on the surface characteristics of the material.

\section{Conclusion}

In this work, the effects of particle sizes on the physicochemical properties of the gum arabic powder were explored. Experimental results indicated that different particle sizes exhibited different physicochemical properties of the above-mentioned powder. This could be explained using experimental parameters that are capable of altering the physical structures of the particle, resulting in significant changes on the physicochemical properties. Apart from that, the present work also found that the coarse (208 to $414 \mu \mathrm{m}$ ) particles displayed better characteristics compared to the commercial gum that is available in the market. In conclusion, the characterisation of physicochemical properties of gum arabic powder provides important information for selecting a specific particle size prior to its potential applications in the food product development.

\section{Conflict of Interest}

The authors declare no conflict of interest.

\section{Acknowledgements}

The authors would like to acknowledge Universiti Putra Malaysia for their financial support to conduct this research. The research work was funded by Putra Grant (Grant No: GP-IPS/2015/9460200). 


\section{References}

Ogunjimi, A.T. and Alebiowu, G. (2013). Flow and consolidation properties of Neem gum coprocessed with two pharmaceutical excipients. Powder Technology, 246, 187-192. https://doi.org/10.1016/ j.powtec.2013.04.051

Ahmad, M. and Benjakul, S. (2011). Characteristics of gelatin from the skin of unicorn leatherjacket (Aluterus monoceros) as influenced by acid pretreatment and extraction time. Food Hydrocolloids, 25(3), 381-388. https:// doi.org/10.1016/j.foodhyd.2010.07.004

Al-Assaf, S., Phillips, G.O., Aoki, H. and Sasaki, Y. (2007). Characterization and properties of Acacia Senegal (L.) Wild. var. Senegal with enhanced properties (Acacia (sen) SUPER GUM): Part 1controlled maturation of Acacia Senegal var. Senegal to increase viscoelasticity, produce a hydrogel form and convert a poor into a good emulsifier. Food Hydrocolloids, 21(3), 319-328. https:// doi.org/10.1016/j.foodhyd.2006.04.011

AOAC. (2002). Official Methods of Analyses of Association of Analytical Chemist. $17^{\text {th }}$ ed. Washington, D.C., USA: AOAC

Bailey A.J. and Paul R.G. (1998). Collagen-A not so simple protein. Journal of Social Leather Technology Chemical, 82(3), 104-110.

Bhushette, P.R. and Annapure, U.S. (2018). Physicochemical, functional and rheological investigation of Soymida febrifuga exudate gum. International Journal of Biological Macromolecules, 111, 1116-1123. https://doi.org/10.1016/ j.ijbiomac.2018.01.117

Carr, R.L. (1965). Classifying flow properties of solids. Chemical Engineering, 72(3), 69-72.

Donovan, J.W. (1979). Phase transitions of the starchwater system. Biopolymers, 18(2), 263-275. https:// doi.org/10.1002/bip.1979.360180204

Dziki, D. (2011). Effect of preliminary grinding of the wheat grain on the pulverizing process. Journal of Food Engineering, 104(4), 585-591. https:// doi.org/10.1002/bip.1979.360180204

Elizalde, B.E., De Kanterewicz, R.J., Pilosof, A.M.R. and Bartholoami, G.B. (1988). Physicochemical properties of food proteins related to their ability to stabilize oil in water emulsions. Journal of Food Science, 53(3), 845-848. https://doi.org/10.1111/ j.1365-2621.1988.tb08968.x

Ezekiel, R., Rana, G., Singh, N. and Singh, S. (2007). Physicochemical, thermal and pasting properties of starch separated from $\gamma$-irradiated and stored potatoes. Food Chemistry, 105(4), 1420-1429. https://doi.org/10.1016/j.foodchem.2007.05.018

Fitzpatrick, J.J., Barringer, S.A. and Iqbal, T. (2004). Flow property measurement of food powders and sensitivity of Jenike's hopper design methodology to the measured values Journal of Food Engineering, 61(3), 399-405. https://doi.org/10.1016/S0260-8774 (03)00147-X

Gabas, A.L., Telis, V.R.N., Sobral, P.J.A. and TelisRomero, J. (2007). Effect of maltodextrin and Arabic gum in water vapor sorption thermodynamic properties of vacuum dried pineapple pulp powder. Journal of Food Engineering, 82(2), 246-252. https://doi.org/10.1016/j.jfoodeng.2007.02.029

Gayathri, R. and Sundara Ganapathy, R. (2018). Extraction and characterization of the gum isolated from Araucaria heterophylla. International Journal of Pharmaceutical Sciences and Research, 9(3), 1062-1067.

Hailing, P.J. (1981). Protein stabilized foam and emulsions. Critical Reviews in Food Science and Nutrition, 15(2), 155-203. https:// doi.org/10.1080/10408398109527315

Hausner, H.H. (1967). Friction conditions in a mass of metal powder. International Journal of Powder Metallurgy, 3(4), 7-13.

Hover, R. (2001). Composition, molecular structure, and physicochemical properties of tuber and root starches: A review. Carbohydrate Polymers, 45(3), 253-267. https://doi.org/10.1016/S0144-8617(00) 00260-5

Jani, B.L., Devani, B.M., Vyas, D.M. and Akbari, S.H. (2016). Quality analysis of Acacia nilotica (Babul) gum exudates. International Journal of Food and Fermentation Technology, 6(2), 637-372. https:// doi.org/10.5958/2277-9396.2016.00061.1

Jiang, T., Feng, L., Zheng, X. and Li, J. (2013). Physicochemical responses and microbial characteristics of shiitake mushroom (Lentinus edodes) to gum arabic coating enriched with natamycin during storage. Food Chemistry, 138(23), 1992-1997. https://doi.org/10.1016/ j.foodchem.2012.11.043

Li, W., Wang, Y., Zhao, H., He, Z., Zeng, M., Qin, F. and Chen, J. (2018). Effects of soluble soy polysaccharides and gum arabic on the interfacial shear rheology of soy $b$-conglycinin at the air/water and oil/water interfaces. Food Hydrocolloids, 76, 123-130.

https://doi.org/10.1016/

j.foodhyd.2017.01.009

Liang, H., Yu, F., Tong, Z., Sun, H. and Zhang, T. (2012). Use of combinations of gum arabic, maltodextrin, and soybean protein to 
microencapsulate Ginkgo leaf extracts and its inhibitory effect on skeletal muscle injury. Carbohydrate Polymers, 88(2), 435-440. https:// doi.org/10.1016/j.carbpol.2011.12.025

Mathew, S. and Abraham, T.E. (2007). Physico-chemical characterization of starch ferulates of different degrees of substitution. Food Chemistry, 105(2), 579 -589 .

j.foodchem.2007.04.032

Makri, E.A. and Doxastakis, G.I. (2006). Study of emulsions stabilized with Phaseolus vulgaris or Phaseoluscoccineus with the addition of Arabic gum, locust bean gum and xanthan gum. Food Hydrocolloid, 20(8), 1141-1152. https:// doi.org/10.1016/j.foodhyd.2005.12.008

Moradi, S. and Anarjan, N. (2019). Preparation and characterization of $\alpha$-tocopherol nanocapsules based on gum arabic-stabilized nanoemulsions. Food Science and Biotechnology, 28(2), 413-421. https:// doi.org/10.1007/s10068-018-0478-y

Mosquera, L.H., Moraga, G. and Martínez-Navarrete, N. (2012). Critical water activity and critical water content of freeze-dried strawberry powder as affected by maltodextrin and Arabic gum. Food Research International, 47(2), 201-206. https:// doi.org/10.1016/j.foodres.2011.05.019

Niu, F.G., Kou, M.X., Fan, J.M., Pan, W.C., Feng, Z.J., $\mathrm{Su}$, Y.J., Yang, Y.J. and Zhou, W.H. (2018). Structural characteristics and rheological properties of ovalbumin-gum arabic complex coacervates. Food Chemistry, 260, 1-6. https://doi.org/10.1016/ j.foodchem.2018.03.141

Nussinovitch, A. (1997). Hydrocolloid applications: gum technology in the food and other industries. London: Blackie Academic and Professional. https:// doi.org/10.1007/978-1-4615-6385-3

Ohwoavworhua, F.A. and Adelakun, T.A. (2005). Some physical characteristics of microcrystalline cellulose obtained from raw cotton of Cochlospermum planchonii. Tropical Journal of Pharmaceutical Research, 4, 501-507. https://doi.org/10.4314/ tjpr.v4i2.14626

Onunkwo, G.C. (2010). Evaluation of Okro gum as a binder in the formulation of thiamine hydrochloride granules and tablets. Research in Pharmaceutical Biotechnology, 2(3), 33-39.

Philips, L.G., Whitehead, D.M. and Kinsella J. (1994). Structure-function properties of food proteins., p. 3451. San Diego, USA: Academic Press.

Pua, C.K., Hamid, N.S.A., Rusul, G. and Rahman, R.A. (2007). Production of drum-dried jackfruit (Artocarpus heterophyllus) powder with different concentration of soy lecithin and gum arabic. Journal of Food Engineering, 78(2), 630-636. https://doi.org/10.1016/j.jfoodeng.2005.10.041

Righetto, A.M. and Netto, F.M. (2005). Effect of encapsulating materials on water sorption, glass transition and stability of juice from immature acerola. International Journal of Food Properties, 8 (2), 337-346. https://doi.org/10.1081/JFP-200060262

Sciarini, L.S., Maldonado, F., Ribotta, P.D., Pérez, G.T. and León, A.E. (2009). Chemical composition and functional properties of Gleditsia triacanthos gum. Food Hydrocolloids, 23(2), 306-313. https:// doi.org/10.1016/j.foodhyd.2008.02.011

Singh, N., Singh, J., Kaur, L., Sodhi, N.S. and Gill, B.S. (2003). Morphological, thermal and rheological properties of starches from different botanical sources-A review. Food Chemistry, 81(2), 1-13. http://doi.org/10.1016/S0308-8146(02)00416-8

Tan, C.T. (2004). Beverage emulsions. In Friberg, S., Larrson, L and Sjoblom, J. (Eds.) Food emulsion. $4^{\text {th }}$ ed., p. 485-524. New York, USA: Marcel Dekker.

Teunou, E. and Fitzpatrick, J.J. (2000). Effect of storage time and consolidation on food powder flowability. Journal of Food Engineering, 43(2), 97-101. https:// doi.org/10.1016/S0260-8774(99)00137-5

Venien, A. and Levieux, D. (2005). Differentiation of bovine from porcine gelatines using polyclonal antipeptide antibodies in indirect and competitive indirect ELISA. Journal of Pharmaceutical and Biomedical Analysis, 39(3-4), 418-424. https:// doi.org/10.1016/j.jpba.2005.04.013

Walsh, D.J., Russell, K. and FitzGerald, R.J. (2008). Stabilisation of sodium caseinate hydrolysate foams. Food Research International, 41(1), 43-52. https:// doi.org/10.1016/j.foodres.2007.09.003

Whistler, R.L. (1993). In Whistler, R.L. and BeMiller, J.N. (Eds.). Industrial gums: Polysaccharides and their derivatives. $3^{\text {rd }}$ ed., p. 309-390. San Diego, USA: Academic Press.

FAO (1998). Compendium of food additive specifications addendum 7. Food and nutrition paper No. 52 Add. 7. Joint FAO/WHO Expert Committee on Food Additives 53rd session Held in Rome, 1-10 June 1999. Rome: Food and Agriculture Organization of the United Nations.

Zhang, L., Zeng, X., Qiu, J., Du, J., Cao, X., Tang, X., Sun, Yong., Li, S., Lei, T., Liu, S. and Lin, L. (2019). Spray-dried xylooligosaccharides carried by gum arabic. Industrial Crops and Products, 135, 330 -343. https://doi.org/10.1016/j.indcrop.2019.04.045 